\title{
DRIVERS OF INTIMATE PARTNER VIOLENCE AGAINST WOMEN IN THREE REFUGEE CAMPS
}

\author{
Karin Wachter \\ The University of Texas at Austin \\ Karin.Wachter@utexas.edu \\ Rebecca Horn \\ Queen Margaret University \\ rebecca.r.horn@gmail.com \\ Elsa Friis \\ Duke University \\ elsa.friis@duke.edu \\ Kathryn Falb \\ The International Rescue Committee, New York City \\ Kathryn.Falb@rescue.org \\ Leora Ward \\ The International Rescue Committee, Washington, D.C. \\ wardleora@yahoo.com \\ Christine Apio \\ The International Rescue Committee, Juba, South Sudan \\ christine.apio@rescue.org \\ Sophia Wanjiku \\ The International Rescue Committee, Nairobi, Kenya \\ sophia.wanjiku@ rescue.org \\ Eve Puffer \\ Duke University \\ eve.puffer@duke.edu
}

Correspondence concerning this article should be addressed to Karin Wachter, Institute on

Domestic Violence \& Sexual Assault, School of Social Work, The University of Texas at Austin,1925 San Jacinto Blvd., Stop D3500, Austin, Texas 78712-1405.

Email: Karin.Wachter@utexas.edu 
RUNNING HEAD: Drivers of intimate partner violence

\section{AUTHOR'S NOTE}

We thank the women and men who participated in this study and shared with us their invaluable expertise. In addition we would like acknowledge Ruth Kimaathi for her assistance in carrying out research in Kenya and to Melanie Megevand for her review of the manuscript.

\section{FUNDING}

The research was funded by the U.S. Department of State's Bureau of Population, Refugees and Migration (S-PRMCO-13-CA-1209).

\section{KEY WORDS}

domestic violence, displacement, qualitative research 
RUNNING HEAD: Drivers of intimate partner violence

\begin{abstract}
This qualitative study examined the "drivers" of intimate partner violence (IPV) against women in displacement to identify protective factors and patterns of risk. Qualitative data were collected in three refugee camps in South Sudan, Kenya and Iraq (N=284). Findings revealed inter-related factors that triggered and perpetuated IPV: gendered social norms and roles, destabilization of gender norms and roles, men's substance use, women's separation from family, and rapid remarriages and forced marriages. These factors paint a picture of individual, family, community and societal processes that exacerbate women's risk of IPV in extreme conditions created by displacement. Implications for policy and practice are indicated.
\end{abstract}


RUNNING HEAD: Drivers of intimate partner violence

\section{INTRODUCTION}

Violence against women is especially ubiquitous in war and displacement (Nawyn, Reosti, \& Gjokaj, 2009). However, research in conflict-affected settings has traditionally focused on the sexual violence women experience by armed actors, overshadowing the global reality that women are at greater risk of intimate partner violence (IPV) across settings (GarciaMoreno et al., 2006; Stark \& Ager, 2011) and growing evidence that indicates that IPV escalates in times of war (Clark et al., 2010; Hossain et al., 2014; Usta, Farver \& Zein, 2008).

Evidence and practice demonstrate that unequal gender-power dynamics and their role in shaping attitudes, norms, behaviors and policies are intrinsically linked to the perpetuation of violence against women (Michau, Horn, Bank, Dutt \& Zimmerman, 2015). Heise's 2011 review of the evidence from low- and middle-income countries using the ecological model brings into focus specific variables associated with IPV against women. Community and societal level predictors of a country's prevalence of IPV include variables related to women's status, gender inequality, social acceptability of violence against women and overall levels of socio-economic development (Heise, 2012). Relationship-level risk factors for both experiencing and perpetrating include conflict in the relationship, male dominance, economic stress, men having multiple partners, and disparities in educational attainment between spouses (Chan, 2008; WHO/LSHTM, 2010). Individual factors associated with men's use of IPV against their female partners include low levels of formal education, maltreatment in childhood or witnessing violence in the family of origin, harmful use of drugs or alcohol, and attitudes that condone violence against women and gender inequality (WHO/LSHTM, 2010). Research and practice point to the need for IPV prevention efforts that span human ecology, employ an intersectional gender-power analysis, promote sustained cross-sectoral programming, draw from theory- and 
RUNNING HEAD: Drivers of intimate partner violence

evidence-informed approaches, encourage personal and collective critical thought, and facilitate activism (see Michau et al., 2015).

Risk factors for IPV in stable settings are expected to persist and be exacerbated by war and displacement, and it is imperative to analyze its occurrence within the context of intersecting gendered oppressions and social norms at play. Armed conflict and displacement not only erode protective social structures but increase daily stressors due to a lack of economic opportunities (Falb, et al., 2014). Displaced persons also often experience profound loss of social status and changes in social roles (Hynes et al., 2015) with implications related to providing for the family and identity. Studies with displaced communities have found a connection between such changes in social roles and marital conflict (Okello \& Hovil, 2007; Carlson, 2005; Ondeko \& Purdin, 2004). Exposure to war-related violence and torture have also been linked to increased rates of men's physical abuse of female partners (Clark et al., 2010; Gupta et al., 2009). Structural factors, including corruption in the police system and rampant poverty, exacerbate and sustain IPV when displaced persons return home (Annan \& Brier, 2010).

While studies have identified associations between consequences of armed conflict and IPV, the current study adds to the literature by using a holistic and inductive approach to explore "drivers" of IPV specifically in three refugee camp contexts. In this study, "drivers" of IPV connote how these factors both trigger initial violence and perpetuate ongoing violence, and we thereby sought to capture the complexity of those factors from the perspective of those directly and indirectly living with IPV. We analyzed qualitative data representing multiple perspectives to identify the most salient individual, interpersonal, and broader contextual drivers of IPV within refugee camp settings. The diversity of contexts included in the study - South Sudan, 
RUNNING HEAD: Drivers of intimate partner violence

Kenya, and Iraq - allowed for the identification of drivers common across camp contexts with the goal of informing practice and policy.

\section{METHODOLOGY}

This study employed a qualitative approach to study the drivers of IPV in three refugee camps. The research was carried out in 2014 by researchers in collaboration with the International Rescue Committee (IRC), an international humanitarian organization with a long history of gender-based violence prevention and response programming.

\section{$\underline{\text { Study Sites }}$}

Study sites were selected based on the IRC's field presence, availability of services and programming, access, information about women's experience of IPV generated through programming, and diversity of context and location. See Table 1.

\section{Ajuong Thok Camp (Republic of South Sudan)}

Approximately 10,466 refugees from Nuba Mountains in South Kordofan were registered in Ajuong Thok camp at the time of data collection. Sudan has experienced civil war since 1955, following nearly 60 years of British control. When the 2011 referendum granted South Sudan independence from the north, South Kordofan became part of north Sudan despite inhabitants identifying as south Sudanese. Since 2011, systematic bombing of South Kordofan and neighboring states has produced over 200,000 refugees.

\section{Dadaab Camp (Republic of Kenya)}

The Dadaab refugee camps were established in 1992. At the time of data collection, 104,865 refugees were registered in Hagadera Dadaab camp. The majority of refugees in the Hagadera Dadaab camp fled from their homes of origin in Somalia, and a small number of participants came from Gambella, Ethiopia. The independent Somali Republic was established in 
RUNNING HEAD: Drivers of intimate partner violence

1960 following independence from Italy and British occupation. Civil war in Somalia, spurred by the 1991 collapse of the Barre regime, has been characterized by instability, violence, and lack of a stable central authority. Ethiopia successfully resisted European colonization, but the period between 1974 and 1991 was characterized by political instability, violence, severe drought and economic strife, culminating in mass migration of Somalis and Ethiopians to Kenya.

\section{Domiz Camp (Republic of Iraq)}

Domiz camp in the Kurdistan region of Iraq was established in April 2012 in response to Kurds fleeing violent conflict in Syria. Approximately 65,041 Syrian Kurds were registered in 2014, double the size of the camp's original design. Syria gained independence from France in 1945, and the post-independence period was characterized by political instability. In 1970, a civilian Ba'ath government took power. Ethnic Kurds in Syria have been systematically persecuted by the al-Assad regime, and have sought independence.

\section{$\underline{\text { Recruitment }}$}

Respondents were recruited from four categories: IPV survivors, members of the general refugee community, refugee leaders and service providers. In each location, a community advisory group (CAG) was established, composed of members of the refugee community and representatives of service providers, to adapt data collection plans and assist with recruitment. Nonprobability purposive sampling strategies were used to recruit participants.

IPV survivors were recruited across a range of demographic characteristics including age, number of years in camp, ethnic group, and marital status. Psychosocial service providers invited women who had sought support from them to participate, and CAG members recruited women who had not reported to a service provider. Group discussion participants were recruited by field staff and the CAGs to represent a broad demographic spectrum of the refugee 
RUNNING HEAD: Drivers of intimate partner violence

population. Service providers were recruited by field staff to represent a range of sectors.

Recruitment strategies varied across the three locations and were specified in collaboration with the organization's field teams in each setting. For survivors, security and access were particularly important considerations.

\section{$\underline{\text { Participants }}$}

Two hundred eighty-four individuals participated in the research across three camps $(\mathrm{N}=284)$. Adult women who experienced IPV and participated in individual interviews $(\mathrm{n}=39)$ ranged in age from 18 to 46 years old (Table 3). Twenty-three group discussions were held with community members ( $n=169)$, organized by gender, language, and age (Table 4). Key informant group discussions were held with female and male refugee leaders $(n=43)$ and service providers ( $\mathrm{n}=30$ ); interviews also were conducted with three additional service providers (Table 4). Service providers represented education, health, law enforcement, community services, camp management, gender-based violence and child protection sectors. The three camps were predominantly Muslim, with the exception of minority groups from Gambella, Ethiopia residing in Dadaab who identify predominately as Christian.

\section{Protection of Human Subjects}

The [authors' affiliated university] Institutional Review Board, the Kenya Medical Research Institute and the Ministry of Health (Kurdistan Regional Government) in Iraq reviewed and approved the study. An ethical review board did not exist at the time in South Sudan. All language interpreters signed a code of conduct that outlined expectations in terms of ethics, personal conduct, confidentiality and protection of information. All participants gave verbal informed consent. Informed consent scripts were used to verbally explain to participants what they needed to know about the study and how the information would be used; these were read 
RUNNING HEAD: Drivers of intimate partner violence

when participants were initially invited to participate and again at the beginning of each interview or group discussion. None of the respondents received compensation for their participation in the study. The research was planned and conducted in accordance with established guidelines on conducting research on domestic violence (WHO, 2001) and on violence against women (Ellsberg \& Heise, 2005). Safety guidelines were developed that addressed the key issues of informed consent, confidentiality, referral systems and reporting procedures. All women survivors of IPV had trained case managers and counselors available to them and were provided with information about local services.

\section{$\underline{\text { Data Collection Procedures }}$}

Data collection took place in the three camps between April and July, 2014. In Ajuong Thok and Domiz, all data were collected by the lead international field researcher with language interpreters. In Dadaab, where security issues prevented the field researcher from entering the camp, group discussions and individual interviews were conducted by IRC staff with training, guidance and supervision from the lead researcher. The data collection process employed a combination of (1) individual interviews, (2) group discussions and (3) key informant interviews and group discussions. Individual interviews were conducted with female survivors of IPV to explore personal experiences of IPV, help-seeking behavior and the factors taken into account when deciding how to seek support and respond. Group discussions were held with members of the refugee community to explore the drivers and nature of IPV in that setting. Discussions with key informants from the refugee community and with representatives of humanitarian organizations were conducted to obtain contextual information, to understand their views on the nature and drivers of IPV. 
RUNNING HEAD: Drivers of intimate partner violence

\section{$\underline{\text { Data Analysis }}$}

The lead researcher conducted a preliminary thematic content analysis of the data immediately following data collection based on the audio recordings, written notes, and transcripts as they were produced to identify key themes (Brain \& Clarke, 2006). This process involved reviewing the data under each of the themes, and summarizing the key issues for presentation during debrief meetings with refugee leaders and representatives of nongovernmental organizations and United Nations agencies. This enabled the lead researcher to ensure that the analysis reflected stakeholders' perceptions of the key issues (Creswell, 2013). The data produced in the first data collection site, Ajuong Thok, was used to develop a preliminary code book. The final coding scheme was developed by a four-person analysis team through discussion, testing, and revisions until the team achieved consensus and the coding scheme worked to capture the salient concepts in the data from all three settings. Examples of relevant codes are included in Table 2. The codes were entered into Dedoose, an on-line analysis software package that facilitates collaboration across multiple coders. Inter-rater reliability was assessed until the four coders achieved $80 \%$ agreement or above across all codes. The team then coded all data using the coding scheme which had been established. To ensure rigor, the coding team had regular meetings to debrief and used the memo function in the software to ensure consistency in coding, to raise queries, and to discuss analytic ideas (Padgett, 2008). The team also utilized a detailed audit trail to document their decision making during the coding and analysis process (Rodgers and Cowles, 1993).

\section{RESULTS}

Results are divided into three categories: contextual considerations, types of IPV, and drivers of IPV. The latter is referred to as "drivers" of IPV to connote how these factors both 
RUNNING HEAD: Drivers of intimate partner violence

trigger initial violence and perpetuate ongoing violence. Understanding these drivers was the major focus of our analysis and discussion.

\section{Contextual Considerations}

The circumstances under which people fled their countries of origin and the contexts in which the camps were established are found in the methods section. Both similarities and differences emerged between the camps in terms of participants' descriptions of the impact of displacement on individuals, families and communities. Participants who had more recently fled their homes of origin spoke in-depth about the extent to which their lives had been dramatically changed by displacement in comparison to those who resided in the camps for a significant amount of time. Across the three study sites, participants described their pre-conflict home communities as tightly knit with well-known community leaders. The study identified a lack of social cohesion in camp populations, and especially in Domiz where people from different communities or geographical areas now lived in close proximity to one another. In all three camps, families had been separated from members of their immediate and/or extended families during displacement and experienced a loss of family cohesion as a result. While basic services were provided by humanitarian organizations and government agencies, including primary and secondary schools, people struggled to obtain essentials (e.g. clothing) and to supplement food rations.

\section{Types of IPV}

Women across the three camps reported experiencing a range of types of IPV, including physical, emotional and sexual violence; men controlling their behavior and movements; and financial or material neglect. General references to beating were the most common descriptions of physical IPV across all camps, with others including punching, slapping, pushing, throwing 
RUNNING HEAD: Drivers of intimate partner violence

objects, burning, and throwing a woman out of the house with force. Physical threats were commonly described, most often by a man threatening to kill his wife with a knife or gun. Participants across all camps reported men forcing their female partners to have sex, with some describing particularly violent force. Refusal of sex could also trigger the other types of physical violence. Participants described how verbal and emotional abuse could occur in the absence of physical abuse or in combination. They also described how some men controlled their wives in other ways, particularly with regards to their movement and social interactions.

\section{Drivers of IPV}

\section{Gendered Social Roles and Norms}

The influence of gendered social norms on violence against women clearly emerged across the three camps. Men's roles were described as the head of the household and financial provider for the family. In contrast, women were expected to be submissive and responsible for child rearing, tending to the needs of the household and sexually satisfying her husband. The values and practices related to these norms were described as contributing to IPV in all three camps in cases where men abused the power ascribed to them by their traditional roles. Much of the conflict reported related to the power differential promoted by the role divisions. Some participants reported that a man beating his wife was socially acceptable in some circumstances, although there were different opinions as to the situations in which this was believed to be warranted. Opinions ranged from condoning beating if a wife is unfaithful to her husband to the belief that a husband must beat his wife to show love. In Dadaab and Ajuong Thok, the acceptability of violence was reinforced by the belief that beating is a tool necessary to teach or correct women (and children), and this was also indirectly discussed in Domiz. The concept of beating to teach was closely linked with the concept of beating a wife in order to promote respect 
and to maintain male control and dominance in the household. Beliefs that men should be able to have sex with their wives at any time were also understood as contributing to IPV against women. When a woman resisted her husband's attempts to have sex, it was seen as acceptable for him to beat her. There was ambivalence among both men and women about who was at fault when a man forced sex or beat a woman who refused sex. Respondents seemed to believe that both parties had acted wrongly, even if they acknowledged that violence by the husband was not an acceptable response. In addition, a woman engaging in sexual relationships outside of the marriage could lead to violence, threats, "returning" a wife to her parents, abandonment, or formal dissolution of the marriage. Rumors of a woman's infidelity could trigger a male spouse to use violence against his wife.

\section{Destabilization of Gender Norms and Roles}

Women noted that they had new opportunities in the camps such as skills training and schools for girls that were not available to them pre-displacement. Some women respondents in Domiz expressed that women's rights were more respected there than in Syria, and that women felt supported by organizations and government bodies in the camp. In contrast, women in Domiz who had lived in more liberal parts of Syria experienced life in the camp as conservative and oppressive; they were no longer able to live independently and had to adapt their clothes and behavior to avoid being judged or attacked. Men in all three camps reported feeling disempowered, frustrated and threatened because they felt their traditional role to protect and provide were usurped by international humanitarian agencies in the camps. Men also described feeling disrespected and insufficiently included in programing in comparison to women, and some believed this was having a negative impact on their values and customs. Many male respondents believed that the emphasis on western ideals by local organizations led their wives 
to be less respectful and more disobedient. In turn, this non-submissive behavior was described as a trigger for violence by both women experiencing IPV as well as community respondents.

A salient subtheme that emerged was partners' unmet expectations of one another, especially on issues related to the provider role and financial resources. Not all respondents adhered to traditional gender roles, but in families where men held more power, women were not consulted in making important decisions and were expected to quietly accept their husbands' actions. In these families, conflict arose when a woman voiced concerns about her husband's behavior, most commonly related to his substance use, relationships with other women, and misuse of resources and rations. Similarly, women asking their spouses for money or goods were cited as situations that would provoke violence. One woman in Dadaab explained that "there was a time that I tried to sit with him to discuss the children's education and [clothes] that I needed. Then after asking, he started slapping and abusing me." Despite the prevailing expectation of men to provide for their family, participants across all camps described men's neglect of the family, failure to contribute productively to the household and/or complete abandonment of the family as a rampant form of abuse adversely affecting women and their children. Women respondents noted that men took less responsibility for their families in Ajuong Thok than they did at home, pre-displacement. Respondents in Dadaab described the majority of men as idle. A key informant in Dadaab described the following:

At home, the man was the breadwinner and got respect because of that. Now this has changed, they have no work, men are idle, and women lose respect for them because they are always in the house, doing nothing...the man is frustrated. 
RUNNING HEAD: Drivers of intimate partner violence

In some cases, men's lack of productivity was attributed to individuals' characters, but most participants described the lack of work opportunities reflective of the kinds of labor men did predisplacement.

Participants described women assuming primary responsibility for the household in Ajuong Thok and Dadaab, and to a lesser extent in Domiz where both men and women were unable to secure employment. In some situations, women's stepping into the void left by men as the main provider for the family was identified as an underlying cause and proximal trigger for men's emotional and physical violence against them. A participant in a female group discussion conducted in Dadaab described this complex role change as follows:

It is now like women have taken the responsibility of men, becoming the breadwinners, getting out of the hut, looking for some other means,...doing any other domestic activity that can help them get their ends meet. I have even seen a case whereby the woman is a porter, she uses wheelbarrow and fetches water around the blocks... when she comes back home the husband will snatch what she [earned].

The failure of either party to meet their traditional gendered responsibilities could lead to a confrontation and culminate in men's perpetration of violence. Accounts of this typically involved either the man or woman asking the other party to fulfill their role or expressing disappointment or anger over the failure to do so. In Ajuong Thok and Dadaab, women were punished for requesting that their husbands fulfill their traditional role as provider, as asking for this necessitated stepping out of their own submissive role. On the other hand, women were punished for assuming the provider role that had been left unfilled, first by the displacement event and then often by their husbands' inability or failure to adapt. While respondents acknowledged that it was difficult for men to provide for their families in the camp context (e.g. 
RUNNING HEAD: Drivers of intimate partner violence

to find work or engage in traditional livelihood activities such as farming), there also were many examples of men earning money, but using it for themselves rather than meeting the needs of their families. Some men actively stole money and resources from their families, demanded to be given money that their wives had earned, or sold the family's possessions or rations.

Confrontations and arguments related to money commonly led to verbal or physical abuse. Participants did not describe this material neglect or maltreatment as 'violence' in the same way they did when discussing physical or verbal violence, but their responses suggest that these issues and conflicts often caused the same level of emotional distress, if not more.

In contrast, participants in all three camps shared examples of cohesive wife-husband partnerships despite shifts in traditional gender roles due to displacement. In these cases, couples were said to collaborate in finding solutions to problems, in recognition that only by depending on each other and trusting each other would the family survive such difficult circumstances intact. These couples discussed concerns and feelings, and demonstrated patience and understanding of one another's circumstances. A female participant in a group discussion in Dadaab said,

I am not saying all man are bad. Maybe some are good. You can even see that some men are happy....they assist with the family even the whole household, they wash for the utensils, they cook food for the family and they are always supportive of the wife at home. And you will see that even their life is better than the one who always harasses their wives.

Another female participant in a group discussion in Domiz said, "if my husband respects me, I will respect him the same time. When my husband comes home, I know that he is tired. I should not at once tell him give me money or like that or do complain for him. I should be patient". In 
RUNNING HEAD: Drivers of intimate partner violence

addition, some mentioned the importance of flexibility, in terms of the ability to take on new roles and responsibilities, to adapt and support the family's wellbeing in the new environment.

\section{Men's Substance Use}

Substance use was discussed as both an underlying factor and a proximal trigger to IPV in Dadaab and Ajuong Thok, but was not cited as an issue in Domiz. In Ajuong Thok, alcohol use was most commonly mentioned whereas discussions in Dadaab revolved around chewing miraa, an amphetamine-like stimulant (also commonly referred to as khat), a common practice in Somali male culture. Alcohol was very rarely consumed in either Domiz or Dadaab. To the contrary, Nubians in Ajuong Thok brewed and drank alcohol as a regular social and cultural practice.

Respondents in Dadaab and Ajuong Thok both described substance use as a coping mechanism used by unemployed males to deal with the stress of camp life and their inability to provide financially for their families. Some men were described as coping poorly with the situation, self-medicating with miraa and alcohol, and increasingly neglecting the household. In an economic context in which families struggled to survive, some men were described as spending resources and substantial amounts of time consuming substances instead of engaging with and contributing to the household. One key informant in Dadaab described,

Some men find the change of lifestyle difficult. Some had good lives at home, and when they come here they miss everything, they become desperate and feel powerless. Some become addicted to miraa.

Male respondents also reported that men's substance use in the camps was perpetuated by general social acceptance and peer pressure to engage in substance use with other men. Participants explained that in Nuba Mountains (pre-displacement) men typically drank alcohol 
RUNNING HEAD: Drivers of intimate partner violence

only on certain special occasions, and alcohol use was governed by social codes or guidelines which limited the extent to which it created problems. For example, in Nuba Mountains men consumed alcohol in close-knit family groups, which served to regulate drinking, whilst in Ajuong Thok they drank in non-kin peer groups.

Men's substance use was cited as a source of tension and trigger for men's violence against their female partners, often through multi-step pathways. Most often, substance use contributed to financial problems affecting the household, with tension revolving around men using income or rations to buy alcohol or miraa. Often overlaid on the tension over use of resources was the wife's overall disapproval of her husband's alcohol or drug use. In some cases, the arguments ignited by this tension became proximal triggers for physical or verbal abuse. This was described by a key informant in Dadaab as follows:

So when the husband goes back at home and the woman notices that this is not the ration that she is entitled to get, and plus where did you get the money to buy miraa? So it becomes a fight, so the next time the wife wants to go take ration, they start fighting. Alcohol in particular was also said to contribute to IPV through its disinhibiting effects. Women who experienced IPV explained how simple discussions could quickly turn violent when their partners had been drinking and also described completely unprovoked beatings from their drunken husbands. Multiple participants also stated IPV only occurred when their partner was drunk. One woman in South Sudan described her experience. "Yeah, if he doesn't drink, we are not going have any problem. We just stay [in peace]. He doesn't even talk about nonsense or quarrel with me." While miraa was less directly associated with violent behavior, some participants felt that it seemed to alter their partner's personality and ability to interact with the family. 
RUNNING HEAD: Drivers of intimate partner violence

\section{Women's Separation from Family}

Women's separation from their parents and extended families was emphasized as a risk factor for IPV. In displacement, families were scattered and many women were separated from their parents in the camps, removing a potential protective factor and source of support. Predisplacement, men were reported more likely to listen to the wife's parents in comparison to other relatives, especially relatives who were younger, female or more distantly related. The parents of the husband could also play a protective role by mediating conflict and/or housing their daughter-in-law when needed. When the husband's family was supportive of the marriage, respondents said there was a good chance of finding a solution to marital problems. Women in all sites reported that in the refugee camp their partners were more likely to exert violence with increased impunity because family members were no longer present to monitor men's behavior or mitigate conflict. Separation also meant that women no longer benefitted from their parent's assistance or advice. One woman in Ajuong Thok described this as follows:

I think that is the reason that is why he is quarrelling me because if the relatives could be there, he could not do [treat] me like this, because in Nuba Mountains he wasn't doing this because of the relatives.

On a broader level, participants described that there was less social cohesion in the camps than pre-displacement, meaning that women could not typically rely on neighbors and people in their community for help. Thus, they did not have these alternative support networks that might have been available pre-displacement even in the absence of family.

While most respondents cited separation from family as a risk factor, some women did describe ways that family members and other close community members can also fuel violence or allow it to occur-both in the home of origin and camp settings. In some cases, the 
RUNNING HEAD: Drivers of intimate partner violence

perpetration of IPV was partly attributed to the actions of the husband's family. In all three camps, participants provided examples of husbands' parents or relatives taking a dislike to the wife, complaining about her to her husband, or telling him that she was unsatisfactory as a wife, which sometimes led to abuse. Some IPV survivors also described the negative influence of friends, neighbors and brothers on their husband's behavior, for example, encouraging him to drink or to ignore what his wife and his relatives advised him, or telling the husband that his wife was behaving in unacceptable ways. In sum, responses reflected the exceptions to the protective nature of the involvement of family and others in the community.

\section{Quick Remarriages and Forced Marriages}

Respondents described the socio-economic circumstances in the camp leading to hasty marriages that could increase women's risk for IPV. Male respondents also noted other changes in traditional marriage practices, such as inter-clan marriages, which occurred in Dadaab, but not in Somalia prior to displacement. In Dadaab, participants discussed men targeting women for personal gain. As one respondent described, "as soon as a woman is divorced, another man will appear wanting to marry her, especially if she has a source of income, remittances, a business or job. Sometimes he just wants to marry her to get access to her money, so this is likely to bring violence." Participants also described an increase in early marriage in some camps as contributing to "misunderstandings" that could escalate into IPV.

Hasty re-marriages included those whereby a woman's husband had died or divorced her, leaving her and the children destitute and vulnerable. In these cases, women with children from a previous marriage were vulnerable to IPV if the new husband resented the presence of another man's children. A woman experiencing IPV in Ajuong Thok described the following: 
RUNNING HEAD: Drivers of intimate partner violence

The husband who has come to take you again after the other has left will not treat all the children the same, he will not love the child who belongs to another father. When he comes with something that he has brought from the market, he will give to his own children... And this is what brings quarrelling. And when you tell the husband, why are you doing this, why are you separating these children? He says, this child belongs to another man. And if you talk to him he will fight you.

Both women and men identified certain traditional marriage practices as protective in their home areas that were now absent in the camps. In pre-displacement settings women may have had little say in when and who they married, and were also at risk of IPV. However, respondents indicated that the involvement of the extended family on both sides in the decision-making was important to protecting women from IPV. Traditional processes included families getting to know one another, during which time violent tendencies could be discovered. The process also increased the likelihood that both the husband and the wife would establish good relationships with their respective in-laws.

\section{DISCUSSION}

The findings from this research reveal inter-related drivers of IPV across three refugee camps. These factors paint a picture of complex and gendered individual, family, community and societal processes that exacerbate women's risk of IPV in conditions created by conflict, displacement and life in refugee camps, along with persistent gender inequalities. Here we discuss the implications of the findings in relation to three areas of relevance to policy and practice: poverty, substance use, and social support. These are issues that in particular reflect the inter-relatedness of the findings and that may be amenable to improvements with targeted programming and policy-level efforts. 
RUNNING HEAD: Drivers of intimate partner violence

First, key stressors explicit in nearly all of the themes were the poverty, unemployment, and lack of resources people experience in the camps. In this study poverty, the lack of livelihood opportunities, and the restrictions imposed upon inhabitants by encampment contributed to challenging traditional gender roles, and men and women's unmet expectations of one another. While the evidence clarifying how changing economic circumstances impact women's risk of IPV is scarce (Heise, 2011), some studies do point towards a link between the two (Horn, Puffer, Roesch, \& Lehmann, 2014; Falb, et al., 2014). As in this study, risk of violence has been found to be associated with cultural expectations regarding gendered economic roles (Heise, 2011). Violence reflects a reclamation of power and control, and may serve as an expression and validation of masculinities under circumstances that intrinsically challenge gendered identities (Rocca, Rathod, Falle, Pande, \& Krishnan, 2009).

The findings beg the question whether economic programming is an effective IPV prevention strategy, a question the international community has taken steps towards answering (Ellsberg et al., 2015), and that appears especially urgent for camp settings. While there is a growing use of cash transfers and other economic-based activities, it remains unclear how these activities may confer additional protection for women. One study conducted in Cote d'Ivoire demonstrated promising decreases in IPV when discussion groups addressing traditional gender norms for couples were incorporated into a women's savings program (Gupta et al., 2013). However, innovative economic programs are often piloted in areas where people have some access to land and legal employment-resources typically not available to people in camps where people's movement and ability to keep livestock or work are restricted. Camp-based income generating activities, or self-reliance schemes, are typically ad hoc and of insufficient scale to have sustained financial or psychosocial impacts. Prevention programming is typically 
RUNNING HEAD: Drivers of intimate partner violence

short-term and conceived in sectoral silos without adequate attention to gendered community and societal forces at play. Alternatively, systematic camp-wide efforts to transform gender dynamics and social norms, redefine men's contributions to the family, and increase viable income-generating opportunities for women and men are promising considerations in designing economic programs that seek to reduce IPV.

Second, men's substance abuse in two out of the three camps was described as a negative coping mechanism, a symptom of men's aforementioned disengagement, a source of women's hardship, frustration and financial strife, and one factor contributing to women's risk and experience of violence. In this study, the role of alcohol is consistent with research that reports an association between drinking and the frequency and severity of IPV (Ellsberg, Peña, Herrera, Liljestrand \& Winkvist, 2000; Karamagi, Tumwine, Tylleskar, \& Heggenhougen, 2006; Rao, 1997) and a recent qualitative study indicating that stressors related to encampment may affect drinking patterns and norms (Ezhard, 2015). As was described in Ajuong Thok, men's substance use may become increasingly acceptable in camp settings as new social norms rapidly emerge and become entrenched. The knowledge-base for substance abuse programming among displaced persons is not yet established and may be an area of intervention to address a range of public health concerns (Roberts \& Ezard, 2015). We do know, however, that ad hoc or fragmented programming and interventions that pathologize individual men's use of violence are not effective (Michau et al., 2015). As an IPV prevention strategy, it is critical that efforts to address substance abuse are situated within a broader gender-based strategy that draws from established principles for IPV prevention programming (see Michau et al., 2015).

Third, the findings support evidence that women's separation from trusted family members and lack of social support increases their overall vulnerability in displacement 
RUNNING HEAD: Drivers of intimate partner violence

(Wachter, et al. 2015). Social support has been shown to play a protective role in reducing women's risk of IPV (Burton, Duvvury, \& Varia, 2000), communicate to women that they matter, build confidence, and avail options during or after violent episodes (Counts \& Brown, 1992). War and displacement ruptures critical social support networks and relationships, dramatically reducing options for women. Since trusted family and community members are often separated in displacement, the role of new neighbors in responding to IPV becomes even more crucial. However, in camps where social cohesion is weak, women may not be able to rely on neighbors and others for support or help, compounding their isolation. Programming should invest in creating opportunities for women to rebuild trusted social support networks in refugee camp settings. Safe spaces, for example, can help women and girls to rebuild community networks and support, and provide a safe entry point for services and a place to access information.

Last, it is important to situate these findings and implications within the context of extreme personal and material loss, compounded by the experience of war, flight and displacement, and the restrictions on human freedoms associated with encampment. The context not only influences the scope and severity of violence against women, but also impacts the community's response and women's options in seeking safety and redress when IPV occurs. The presence, policies, and practice of the humanitarian community are also essential considerations in understanding the context in which violence against women is perpetrated in order to develop the most appropriate response (Horn, 2010). Finally, it is important not to lose sight of the fact that IPV existed prior to the humanitarian crisis and that the findings point to how risk persists and is exacerbated in displacement.

\section{$\underline{\text { Limitations }}$}


RUNNING HEAD: Drivers of intimate partner violence

Several limitations should be noted. First, varying quality of language interpretation was a challenge in all three locations, which influenced the field researcher's ability to build rapport with respondents and manage group discussions. Identifying women who had adequate interpretation experience was a particular challenge in each of the field sites. This was partially addressed by hiring transcribers fluent in the language participants spoke, so that as they transcribed the English content of the voice recordings, they could also listen to the speech in the local language and add in respondents' speech that had not been translated into English during the discussion. Second, the study used a nonprobability purposive sampling strategy, limiting the perspectives represented in the data and potential transferability of the findings. Third, as previously noted, some differences emerged in drivers of IPV across the three camps. While focusing on commonalities contributed to informing more broadly applicable recommendations, understanding these differences will be an important area for future research to inform tailoring of response strategies. Fourth, security issues impacted data collection in each site, which caused delays and restricted the field researchers' movement and access to varying degrees. Researching IPV in many contexts can be dangerous for the participants as well as the researchers. As previously mentioned, specific measures were put into place to safeguard participants. The security concerns that limited the lead researcher's access at times were not related to the research or scope of the research for this particular project but reflected general downturns in security in the areas in which the research took place. In contexts impacted by humanitarian crises IPV studies, especially of this size and scope, require on the ground support from established actors as well as detailed planning and tremendous flexibility. Last, as we chose to devote this paper to an in-depth description and analysis of the data, thereby bringing to the forefront the voices of the participants, this limited our attention to the theoretical implications. 
RUNNING HEAD: Drivers of intimate partner violence

\section{CONCLUSION}

Key drivers of IPV across refugee camp settings were found to be an inter-related blend of factors triggering and perpetuating violence against women. These drivers demonstrated the ways that women, men, and their relationships with one another are destabilized as a result of displacement and within refugee camp contexts. In particular, the drastic disruptions to the ways in which people provide for their families and the ways in which families and communities live together and support one another are underlying themes that subsume the drivers of IPV identified in this study. The complex interactions between these disruptions and gendered norms and power imbalances are clear. Findings from this study point to potential specific avenues for programming in the areas of economic, substance abuse, and social support interventions that could be implemented alongside broader prevention efforts that seek to shift power dynamics at multiple levels. Strategies targeting these factors will require careful consideration and evaluation, coordinated and sustained efforts, and the involvement of the communities they seek to assist. 
RUNNING HEAD: Drivers of intimate partner violence

\section{REFERENCES}

Annan, J., \& Brier, M. (2010). The risk of return: Intimate partner violence in Northern Uganda's armed conflict. Social Science \& Medicine, 70(1), 152-159.

Braun, V. and V. Clarke (2006). Using Thematic Analysis in Psychology. Qualitative Research in Psychology, 3(2): 77-101.

Burton, B., Duvvury, N., \& Varia, N. (2000). Domestic violence in India: a summary report of a multi-site household survey. Washington: International Centre for Research on Women.

Carlson, S. (2005). Contesting and reinforcing patriarchy: an analysis of domestic violence in the Dzaleka Refugee Camp (Working Paper). Oxford: University of Oxford. Retrieved from: http://www.rsc.ox.ac.uk/files/publications/working-paper-series/wp23-contestingreinforcing-patriarchy-2005.pdf

Chan, K. L. (2008). Sexual violence against women and children in Chinese societies. Trauma, Violence, \& Abuse, 10(1), 69-85.

Clark, C. J., Everson-Rose, S. A., Suglia, S. F., Btoush, R., Alonso, A., \& Haj-Yahia, M. M. (2010). Association between exposure to political violence and intimate-partner violence in the occupied Palestinian territory: A cross-sectional study. The Lancet, 375(9711), 310-316.

Counts, D. A., \& Brown, J. K. (1992). Sanctions and sanctuary: Cultural perspectives on the beating of wives. Boulder, CO: Westview Press.

Creswell, J. W. (2013). Research design: Qualitative, quantitative, and mixed methods approaches. Sage publications. 
RUNNING HEAD: Drivers of intimate partner violence

Ellsberg, M., Arango, D. J., Morton, M., Gennari, F., Kiplesund, S., Contreras, M., \& Watts, C. (2015). Prevention of violence against women and girls: What does the evidence say?. The Lancet, 385(9977), 1555-1566.

Ellsberg, M., \& Heise, L. (2005). Researching Violence Against Women: A Practical Guide for Researchers and Activists. Washington DC, United States: World Health Organization, PATH.

Ellsberg, M., Peña, R., Herrera, A., Liljestrand, J., \& Winkvist, A. (2000). Candies in hell: women's experiences of violence in Nicaragua. Social Science \& Medicine, 51(11), 1595-1610.

Ezard, N. (2014). It's not just the alcohol: Gender, alcohol use, and intimate partner violence in Mae La Refugee Camp, Thailand, 2009. Substance use \& misuse, 49(6), 684-693.

Falb, K. L., Annan, J., King, E., Hopkins, J., Kpebo, D., \& Gupta, J. (2014). Gender norms, poverty and armed conflict in Côte D'Ivoire: engaging men in women's social and economic empowerment programming. Health education research, 29(6), 1015-1027.

Garcia-Moreno, C., Jansen, H. A., Ellsberg, M., Heise, L., \& Watts, C. H. (2006). Prevalence of intimate partner violence: findings from the WHO multi-country study on women's health and domestic violence. The Lancet, 368(9543), 1260-1269.

Gupta, J., Falb, K. L., Carliner, H., Hossain, M., Kpebo, D., \& Annan, J. (2014). Associations between exposure to intimate partner violence, armed conflict, and probable PTSD among women in rural Côte d'Ivoire. PLOS ONE. DOI: 10.1371/journal.pone.0096300

Gupta, J., Acevedo-Garcia, D., Hemenway, D., Decker, M. R., Raj, A., \& Silverman, J. G. (2009). Premigration exposure to political violence and perpetration of intimate partner violence among immigrant men in Boston. American journal of public health, 99(3), 462. 
RUNNING HEAD: Drivers of intimate partner violence

Heise, L. L. (2012). Determinants of partner violence in low and middle-income countries: exploring variation in individual and population-level risk. Doctoral dissertation, London School of Hygiene \& Tropical Medicine.

Heise, L. (2011). What Works to Prevent Partner Violence? An Evidence Overview. Working Paper. STRIVE Research Consortium, London School of Hygiene and Tropical Medicine, London.

Horn, R. (2010). Exploring the impact of displacement and encampment on domestic violence in Kakuma refugee camp. Journal of refugee studies, 23(3), 356-376.

Horn, R., Puffer, E. S., Roesch, E., \& Lehmann, H. (2014). Women's perceptions of effects of war on intimate partner violence and gender roles in two post-conflict West African Countries: consequences and unexpected opportunities. Conflict and health, 8(1), 12.

Hossain, M., Zimmerman, C., Kiss, L., Kone, D., Bakayoko-Topolska, M., KA, D. M., ... \& Watts, C. (2014). Men's and women's experiences of violence and traumatic events in rural Cote d'Ivoire before, during and after a period of armed conflict. BMJ open, 4(2), $\mathrm{e} 003644$.

Hynes, M. E., Sterk, C. E., Hennink, M., Patel, S., DePadilla, L., \& Yount, K. M. (2015). Exploring gender norms, agency and intimate partner violence among displaced Colombian women: A qualitative assessment. Global public health, 1-17.

Jewkes, R. (2002). Intimate partner violence: Causes and prevention. The Lancet, 359(9315), 1423-1429.

Karamagi, C. A., Tumwine, J. K., Tylleskar, T., \& Heggenhougen, K. (2006). Intimate partner violence against women in eastern Uganda: Implications for HIV prevention. BMC public health, 6(1), 284. 
RUNNING HEAD: Drivers of intimate partner violence

Michau, L., Horn, J., Bank, A., Dutt, M., \& Zimmerman, C. (2015). Prevention of violence against women and girls: lessons from practice. The Lancet, 385(9978), 1672-1684.

Nawyn, S. J., Reosti, A., \& Gjokaj, L. (2009). Gender in Motion: How Gender Precipitates International Migration. Perceiving gender locally, globally, and intersectionally, 13, $175-202$.

Okello, M. C., \& Hovil, L. (2007). Confronting the reality of gender-based violence in northern Uganda. International Journal of Transitional Justice, 1(3), 433-443.

Ondeko, R., \& Purdin, S. (2004). Understanding the causes of gender-based violence. Forced Migration Review, (19), 30.

Padgett, D. (2008) Qualitative Methods in Social Work Research, vol. 36. Los Angeles, CA: SAGE.

Rao, V. (1997). Wife-beating in rural South India: A qualitative and econometric analysis. Social science \& medicine, 44(8), 1169-1180.

Roberts, B., \& Ezard, N. (2015). Why are we not doing more for alcohol use disorder among conflict-affected populations?. Addiction, 110(6), 889-890.

Rodgers, B. L., \& Cowles, K. V. (1993). The qualitative research audit trail: A complex collection of documentation. Research in nursing \& health, 16(3), 219-226.

Stark, L., \& Ager, A. (2011). A systematic review of prevalence studies of gender-based violence in complex emergencies. Trauma, Violence, \& Abuse,12(3), 127-134.

Usta, J., Farver, J. A. M., \& Zein, L. (2008). Women, war, and violence: Surviving the experience. Journal of Women's Health, 17(5), 793-804.

Wachter, K., Heffron, L. C., Snyder, S., Nsonwu, M. B., \& Busch-Armendariz, N. B. (2015). Unsettled integration: Pre-and post-migration factors in Congolese refugee women's 
RUNNING HEAD: Drivers of intimate partner violence

resettlement experiences in the United States. International Social Work, DOI:

0020872815580049.

World Health Organization (2001). Putting women first: Ethical and safety recommendations for research on domestic violence against women. Geneva: World Health Organization.

World Health Organization \& London School of Hygiene and Tropical Medicine (2010).

Preventing intimate partner and sexual violence against women: taking action and generating evidence. Geneva/London: World Health Organization/London School of Hygiene and Tropical Medicine. 
RUNNING HEAD: Drivers of intimate partner violence

Table 1 - Research sites by camp

\begin{tabular}{llll}
\hline \multicolumn{1}{c}{ Ajuong Thok } & \multicolumn{1}{c}{ Hagadera } & \multicolumn{1}{c}{ Domiz } \\
\hline $\begin{array}{l}\text { Established } \\
\text { Location }\end{array}$ & 2013 & 1992 & 2012 \\
& $\begin{array}{l}\text { Unity state, South } \\
\text { Sudan }\end{array}$ & North-eastern Kenya & $\begin{array}{l}\text { Dohuk Governorate of } \\
\text { Kurdistan Region-Iraq }\end{array}$ \\
$\begin{array}{l}\text { Population at } \\
\text { the time }\end{array}$ & $\begin{array}{l}\text { 10,446 } \\
\text { (April 2014) }\end{array}$ & $\begin{array}{l}\text { 104,865 } \\
\text { (July 2014) }\end{array}$ & $\begin{array}{l}\text { 65,041 } \\
\text { (June 2014) }\end{array}$ \\
$\begin{array}{l}\text { Nationalities/ } \\
\text { ethnicities }\end{array}$ & $\begin{array}{l}\text { Predominantly Nubian } \\
\text { Sudanese, from South } \\
\text { Kordofan (Nuba } \\
\text { Mountains) }\end{array}$ & $\begin{array}{l}\text { Predominantly Somali, } \\
\text { with smaller Anywaa and } \\
\text { Oromo populations from }\end{array}$ & $\begin{array}{l}\text { Predominantly Syrian } \\
\text { Kurds, with smaller } \\
\text { Syrian Arabs and }\end{array}$ \\
& & $\begin{array}{l}\text { Ethiopia } \\
\text { Romani populations }\end{array}$ \\
\hline
\end{tabular}


RUNNING HEAD: Drivers of intimate partner violence

Table 2 - Example of the code book

\begin{tabular}{lll}
\hline Major code & Sub-code & Examples \\
$\begin{array}{l}\text { Contextual } \\
\text { information }\end{array}$ & $\begin{array}{l}\text { Life at home pre- } \\
\text { displacement }\end{array}$ & $\begin{array}{l}\text { How participants lived both before the war began } \\
\text { and after before displacement. How life changed } \\
\text { at the onset of war. Nature of IPV, including } \\
\text { causes and effects. }\end{array}$ \\
Life in the camp & $\begin{array}{l}\text { Included alcohol and drug use, overcrowding, } \\
\text { security, the impact of humanitarian } \\
\text { organizations, access to employment and } \\
\text { economic activity in general, separation of } \\
\text { families. }\end{array}$ \\
& History surrounding & $\begin{array}{l}\text { Included information from interviews with IPV } \\
\text { survivors who described the history of their } \\
\text { marriage before displacement, as well as any } \\
\text { patterns of abuse over time. }\end{array}$ \\
survivors' experience of & IPV & $\begin{array}{l}\text { Reference to specific types of IPV described by } \\
\text { participants. }\end{array}$ \\
Fature of IPV & Types & $\begin{array}{l}\text { General underlying factors described by } \\
\text { participants that create the conditions for IPV } \\
\text { perpetration. }\end{array}$ \\
contributing to & Underlying factors & $\begin{array}{l}\text { The events and circumstances described by } \\
\text { participants as triggering or leading to specific } \\
\text { incidents of IPV. }\end{array}$ \\
\hline
\end{tabular}


RUNNING HEAD: Drivers of intimate partner violence

Table 3 - Individual interviews

\begin{tabular}{|c|c|c|c|}
\hline & Ajuong Thok & Hagadera & Domiz \\
\hline $\begin{array}{l}\text { Adult women who } \\
\text { experienced IPV }\end{array}$ & 14 & 15 & 10 \\
\hline $\begin{array}{l}\text { Mean age in years } \\
\text { (range) }\end{array}$ & $\begin{array}{c}27.5 \\
(20-45)\end{array}$ & $\begin{array}{c}34 \\
(21-46)\end{array}$ & $\begin{array}{c}30 \\
(18-40)\end{array}$ \\
\hline $\begin{array}{l}\text { Mean time in camp } \\
\text { (range) }\end{array}$ & $\begin{array}{c}10 \text { months } \\
(3-13 \text { mths })\end{array}$ & $\begin{array}{c}15.3 \text { years } \\
(5-23 \text { years })\end{array}$ & $\begin{array}{l}18.5 \text { months } \\
(3-24 \text { mths })\end{array}$ \\
\hline $\begin{array}{l}\text { Mean length of } \\
\text { marriage (range) }\end{array}$ & $\begin{array}{c}10.5 \text { years } \\
(3-28 \text { years })\end{array}$ & $\begin{array}{c}13 \text { years } \\
\text { (1-25 years) }\end{array}$ & $\begin{array}{c}9 \text { years } \\
\text { (2 mths-23yrs) }\end{array}$ \\
\hline $\begin{array}{l}\text { Mean number of } \\
\text { children (range) }\end{array}$ & $\begin{array}{c}4 \\
(0-9)\end{array}$ & $\begin{array}{c}6 \\
(2-14)\end{array}$ & $\begin{array}{c}3 \\
(0-10)\end{array}$ \\
\hline \multicolumn{4}{|l|}{ Formal education } \\
\hline None & 7 & 9 & 3 \\
\hline Primary & 6 & 4 & 3 \\
\hline Secondary & 1 & 2 & 2 \\
\hline Post-secondary & 0 & 0 & 2 \\
\hline
\end{tabular}


RUNNING HEAD: Drivers of intimate partner violence

Table 4 - Group discussions and interviews with community members and key informants

\begin{tabular}{|c|c|c|c|}
\hline & $\begin{array}{l}\text { Ajuong } \\
\text { Thok }\end{array}$ & Hagadera & Domiz \\
\hline \multicolumn{4}{|c|}{ Group discussions with community members } \\
\hline $\begin{array}{l}\text { Female groups } \\
\text { (individuals) }\end{array}$ & $\begin{array}{l}4 \text { groups } \\
(30)\end{array}$ & $\begin{array}{l}4 \text { groups } \\
(32)\end{array}$ & $\begin{array}{l}4 \text { groups } \\
(30)\end{array}$ \\
\hline $\begin{array}{l}\text { Male groups } \\
\text { (individuals) }\end{array}$ & $\begin{array}{l}4 \text { groups } \\
(23)\end{array}$ & $\begin{array}{l}4 \text { groups } \\
(32)\end{array}$ & $\begin{array}{l}3 \text { groups } \\
(22)\end{array}$ \\
\hline \multicolumn{4}{|c|}{ Key informant group discussions and interviews } \\
\hline $\begin{array}{l}\text { Female refugee leaders } \\
\text { (individuals) }\end{array}$ & $\begin{array}{l}1 \text { group } \\
(8)\end{array}$ & $\begin{array}{l}1 \text { group } \\
(8)\end{array}$ & $\begin{array}{l}1 \text { group } \\
(7)\end{array}$ \\
\hline $\begin{array}{l}\text { Male refugee leaders } \\
\text { (individuals) }\end{array}$ & $\begin{array}{l}1 \text { group } \\
(6)\end{array}$ & $\begin{array}{l}1 \text { group } \\
(9)\end{array}$ & $\begin{array}{l}1 \text { group } \\
(5)\end{array}$ \\
\hline $\begin{array}{l}\text { Service providers } \\
\text { (individuals) }\end{array}$ & $\begin{array}{l}2 \text { groups } \\
(9)\end{array}$ & $\begin{array}{l}2 \text { groups } \\
(11) \\
2 \text { interviews } \\
\text { (2) }\end{array}$ & $\begin{array}{l}1 \text { group } \\
\text { (10) } \\
1 \text { interview } \\
\text { (1) }\end{array}$ \\
\hline
\end{tabular}


RUNNING HEAD: Drivers of intimate partner violence

\section{BIOGRAPHIES}

Karin Wachter is a doctoral candidate at The University of Texas at Austin School of Social Work and a Project Director at the Institute on Domestic Violence \& Sexual Assault (IDVSA). Previously, Karin was with the International Rescue Committee as a humanitarian aid worker responding to violence against women and girls in conflict affected contexts. The focus of Karin's current research is women's social support mechanisms in forced migration.

Rebecca Horn is an independent Psychosocial Specialist and a Research Fellow with the Institute of Global Health and Development at Queen Margaret University, UK. Her research is broadly related to psychosocial wellbeing in areas affected by conflict, displacement or disaster, with a focus on gender-based violence. As a practitioner, her work has included managing psychosocial programs in refugee camps, and supporting organizations to integrate communitybased psychosocial approaches into their programs in humanitarian settings.

Elsa Friis is a doctoral student in clinical psychology at Duke University. She received her Master's in global health from Duke University in 2014. Her research primary focuses on development of sustainable technology-assisted community-based interventions to promote positive family functioning, improve child mental health and prevent HIV risk behavior in lowresource contexts globally.

Kathryn Falb is a Technical Research Advisor at the International Rescue Committee where she focuses on evaluating programming to understand what works to prevent and respond to violence against women and girls in humanitarian emergencies. She is also a Visiting Scientist with the 
RUNNING HEAD: Drivers of intimate partner violence

Harvard TH Chan School of Public Health and Senior Fellow with the Harvard Humanitarian Initiative. Kathryn is trained as a social epidemiologist and holds a ScD from the Harvard School of Public Health.

Christine Apio has over 9 years of experience advocating, implementing, managing and coordinating gender based violence interventions and service delivery in complex humanitarian contexts including South Sudan, Ethiopia, Sudan, Uganda, Rwanda and Tanzania. She has worked with various international humanitarian organizations, including the International Rescue Committee. Christine is currently pursuing an Advanced Masters in Governance and Development in Belgium.

Leora Ward has more than ten years of experience working on violence against women and girls in humanitarian contexts. As Program Analyst at the State Department, Bureau for Population, Refugees and Migration she is responsible for overseeing gender equality policy and programs in refugee contexts. Prior, Leora was Senior Technical Advisor at the International Rescue Committee where she provided strategic direction, thought leadership, and technical support to women's protection and empowerment programs around the world.

Sophia Wanjiku holds Master's degrees in Gender and Development studies, International Cooperation, and Humanitarian Aid. She has 15 years' experience with nongovernmental organizations in eastern Africa, including Mercy Corps, Women for Women International and Kenyan national organizations. As a Technical Advisor with the International Rescue Committee 
RUNNING HEAD: Drivers of intimate partner violence

for Women's Protection and Empowerment, Sophia is currently providing support to programs in Kenya, Uganda, Somalia, South Sudan, Ethiopia and Zimbabwe.

Eve Puffer is an Assistant Professor at Duke University in the Department of Psychology and Neuroscience and the Duke Global Health Institute. She is a global mental health researcher and a licensed clinical psychologist. Her research focuses primarily on developing and evaluating integrated community-based interventions to promote child mental health, improve family functioning, and prevent HIV risk behavior in low-resource contexts, including post-conflict settings. Before joining Duke, Eve was a research advisor at the International Rescue Committee. 